\title{
Historein
}

Vol 16, No 1-2 (2017)

Greek Historiography in the 20th Century: Opening a Research Agenda

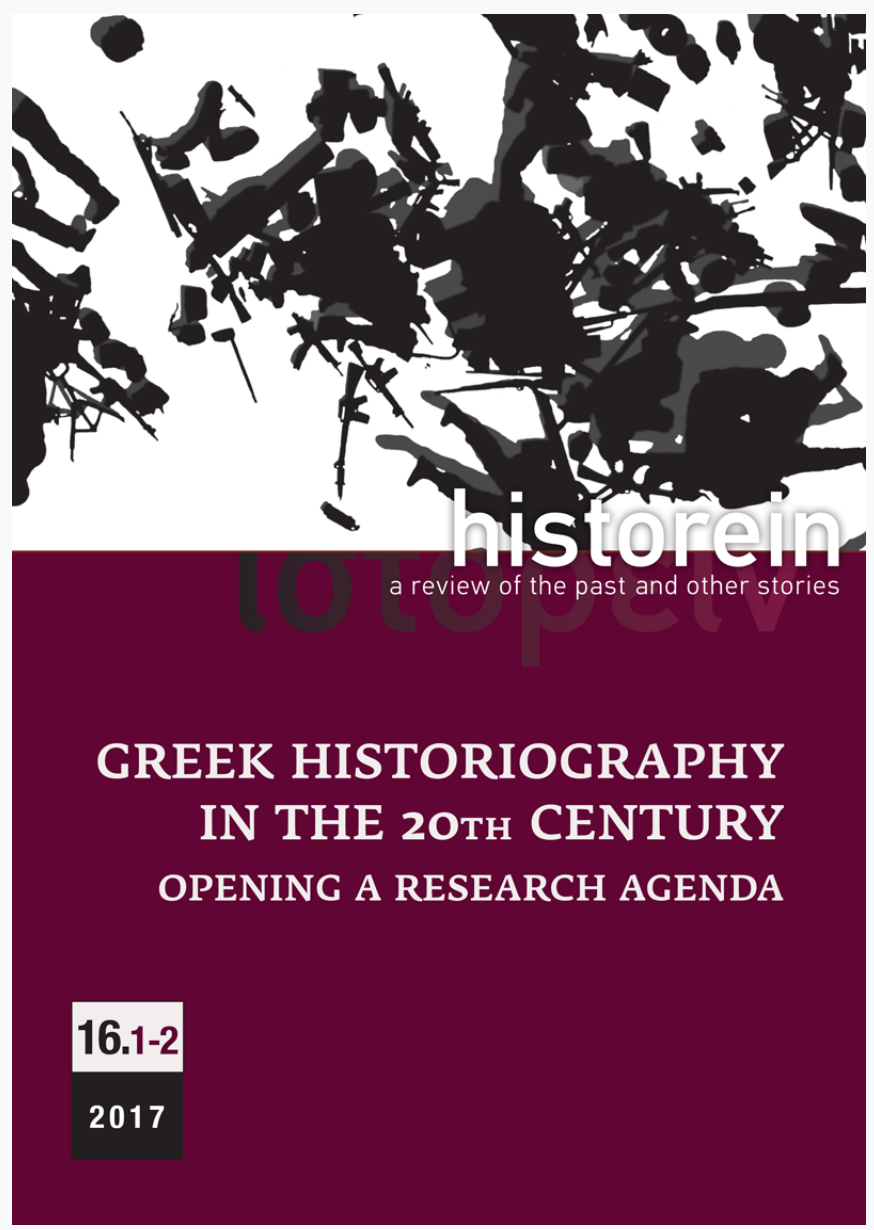

Reflections on the historiography of the twentieth century from the perspective of the twenty-first century

Georg lggers

doi: $10.12681 /$ historein.10416

Copyright @ 2017, Georg lggers

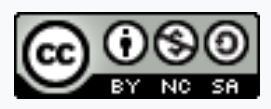

This work is licensed under a Creative Commons Attribution-NonCommercialShareAlike 4.0.

To cite this article:

Iggers, G. (2017). Reflections on the historiography of the twentieth century from the perspective of the twenty-first century. Historein, 16(1-2), 149-158. https://doi.org/10.12681/historein.10416 
The following, an attempt to critically assess the historiography of the twentieth century and the early twenty-first century, are admittedly personal reflections open to discussion and challenge, with a focus on what I consider the shortcomings of historiography today.

I do not primarily wish to offer a survey of historiography over the past century, but rather a perspective which is both critical and as far as possible global. I proceed from the assumption that historiography as we know it is a product of the last two centuries with its roots in specifically western thought. Of course, as we are increasingly realising, all cultures possessed a historical consciousness and many possessed also historical writing; yet what distinguishes history as it developed in the last two centuries from all earlier forms of historiography is the professionalisation of historical studies. To be sure, China had a historical profession going back many centuries, but in a political and intellectual setting very different from the academic discipline which developed in the west in the early nineteenth century. The latter despite its western origins ultimately became the norm worldwide.

I see three major directions in which professional historical studies went since their beginnings in the nineteenth century. I shall identify them as the Rankean, the social history and the culturalist models. I shall further identify a subdivision of social history, namely social science history. I do not consider them to be paradigms in the sense in which Thomas Kuhn uses the term in his The Structure of Scientific Revolutions for which he presupposes a broad consensus among scientists which simply does not exist among historians. Although each of the three models

\section{Reflections on the} historiography of the twentieth century from the perspective of the twenty-first century

\section{Georg lggers}

University of Buffalo 
dominated a great deal of historical theory and writing in a given epoch, there have always been historians who have gone in very different directions, and there has been a good deal of overlap.

\section{The Rankean Model}

To understand where historical studies stand today, we must go back to the transformation of history into an academic discipline in the nineteenth century. We can date the origins of this discipline with the founding of the University of Berlin in 1810 as a modern research university. With Leopold von Ranke, who joined the University of Berlin in 1825, no history was to be written henceforth which did not rely on the critical examination of primary sources. It was no longer the common educated person who could write history, but it took the professionally trained historian to do so. A whole culture of professional historical studies developed which, in many ways, still shapes history today and, as I shall argue, remains responsible for serious limitations of historiography. The Rankean model of professional scholarship was adopted in much of Europe, the United States, and very early in Meiji Japan, somewhat later in China, India, Latin America and, with decolonisation, in Sub-Saharan Africa. In a sense, it was part of a process of modernisation which imposed itself on the rest of the world in an age of western imperialism and expansion.

In fact, what took place has to be understood in its political and social context. The political setting in which professionalisation along the Rankean model occurred is well known; the social and particularly the economic one much less. The background was, of course, the French Revolution and the Napoleonic wars. The Congress of Vienna after the defeat of Napoleon undid many of the reforms of the Napoleonic era. The absolute power of the Hohenzollern monarchy remained intact, in conjunction with a professional bureaucracy, which consisted largely of academically educated civil servants. But the social and economic reforms enacted by Prussia in 1806, which did away with major remnants of the feudal system, remained intact. Thus, a compromise emerged in Prussia, which was similar in other European states, between an old political and a modern social order, the latter involving the Bürgertum, elements of the middle classes. Afraid of the rising lower classes, the German middle classes largely supported a monarchy that only slowly made concessions to a very limited constitutional government. All of this directly affected history, which focused on the state. Thus, historical studies, as carried out by historians who were part of a professional bureaucracy, defended not only the interests of the state, but also those of the Bürgertum.

\section{The replacement of the Rankean by social history and social science models}

Under the very different conditions of industrialisation, urbanisation and the formation of mass societies, the Rankean model appeared increasingly outdated by the turn to the twentieth century. Simultaneous in most European countries, in the US, and Japan, and somewhat belatedly in Latin America and China, historians turned away from a narrow, event-oriented political history to one which analysed social structures and processes of change. We can name important histori- 
ans and theorists of history such as Henri Berr and Lucien Febvre in France, Henri Pirenne in Belgium, Karl Lamprecht in Germany, Charles Beard in the US, Vaseli Kliuchevski and Pavel Milkiukov in Russia, and the husband and wife teams Beatrice and Sidney Webb, and John and Barbara Hammond in England. They all pursued an interdisciplinary approach that placed political structures and processes in a broader social and economic context. Much later, some historians in the post-Second World War period turned to the new computer technology to introduce quantification into historical studies, not only in the US in economic history, but also in France, to study changing mentalities, and in Britain to examine demographic developments. The French historian Emmanuel Le Roy Ladurie as late as 1973 stated that "history that is not quantifiable cannot claim to be scientific", ' a position from which, as we shall see, he soon retreated. The British historian Geoffrey Barraclough, in a survey for UNESCO on recent trends in history, wrote: "The search for quantity is beyond all doubt the most powerful of the new trends in history, the factor above all others which distinguishes historical attitudes in the 1970s from historical attitudes in the 1930s." ${ }^{2}$ An extreme example for this was Robert Fogel and Stanley Engerman's computer-based study in 1974 in which, on the basis of empirical, statistical evidence, they claimed to arrive at irrefutable answers on the controversial questions of the conditions of life of the slaves in the American South. ${ }^{3}$ For the most part, with some notable exceptions, this new social science, unlike the more reform-minded older social history, fitted in well into the highly dynamic technological established capitalist order.

\section{Basic assumptions of history as an academic discipline}

Despite the fundamental differences in historical and social outlook between the Rankean, the social history and the social science history models, they shared certain basic assumptions which deeply affected the ways in which their practitioners wrote history. These basic assumptions were emphatically challenged in the last third of the twentieth century. The first of these assumptions involved the belief in the scientific character of historical studies, and the second the belief in the coherence of history. Both convictions held sway well into the second third of the twentieth century, when they were challenged by what we have described as the culturalist model.

We must, however, keep in mind that the German term "science" (Wissenschaft) has a different meaning than the English term "science", which refers more closely to the natural sciences and their methodologies. In English, history is more commonly viewed as a form of scholarship, rather than as a science. In all continental European as well as East Asian languages, the meaning of the term "science" is closer to its German than to its English meaning. In German, Wissenschaft refers to methodologically strict forms of inquiry which demand professional training. Science and professionalism are thus intertwined.

Unlike the natural sciences, the humanities such as history are not dealing with establishing abstractions, which may lend themselves to quantitative formulations, but seek to comprehend (verstehen) the meaning and intentions of human beings, individually and collectively, which cannot be formulated abstractly but have to take into account their individual character. Thus, all areas of human activity are capable of being studied "scientifically"; or better said "in a scholarly manner". 
There is thus a science of literature, Literaturwissenschaft, a science of art (Kunstwissenschaft), a science of religion, Religionswissenschaft, etc. While in the first half of the twentieth century social science-oriented historians distanced themselves from this loose definition of a humanistic science, they did so because they wanted an even stricter conception of science, closer to the methodologies of the natural sciences.

The second basic conviction held by the bulk of nineteenth-century Rankeans and twentieth-century social and social science historians consisted in the belief in the coherence of history. The older idea that historians recount "histories" was replaced by the idea that history had a direction, that one could discern what is historically significant and what is not. For many this spelled out progress in the direction of the norms of western civilisation. At a later stage, the concept of progress was replaced by that of modernisation. Inherent in the ideas of progress and modernisation was a strong dose of Eurocentrism, an idea which later was widely repudiated but by no means overcome.

Thus, a culture of professionalisation developed which was parallel in all humanitarian and scientific disciplines. To be considered scientific or scholarly, studies had to be conducted in a professional manner. There were similar ways in which historians and scientists were trained, the ways academic degrees counted in recruitment and promotion. Scientific and scholarly organisations were founded, first primarily on a national, later an international level, together with peer-reviewed journals. The way history was conducted henceforth and still is, thus, differed from the way in which it had been conducted before, since classical antiquity. In the west historians from Thucydides to Edward Gibbon were not bound to a university or an academic institution, Their writings combined literature with scholarship. Now, beginning with the Rankean model a clear distinction was drawn between history and literature. Yet this distinction has been overstressed in later assessments of nineteenth-century historiography. Ranke launched the critical evidential approach to history with the often-cited comment that he "wants merely to show what actually happened" (wie es eigentlich gewesen). But he also shortly thereafter wrote: "History is distinguished from all other sciences in that it is also an art." Here critical scholarship and literature merged. And Ranke, as did many who followed him, did not write primarily for specialists, but for a broad public, who read him and viewed his writings as great literature. It is not surprising that Theodor Mommsen, who in his narratives on Roman history applied strict standards of source criticism, was awarded the Nobel Prize for Literature in 1902, the second time that it was given. A great deal of history was written outside academia, not only in the forms of novels but also of historical narratives. The sharp division between academic and nonacademic history is a development of the twentieth century, which still continues. To some extent it has been bridged by the important role which the film and the TV now play.

\section{An assessment of the positive and negative sides of the professional models prior to the culturalist challenge}

Now I will turn briefly to the positive and the negative sides of professionalisation. Of course, professionalisation contributed a great deal to our understanding of the past by requiring a greater reliance on the critical examination of sources. It brought together two major orientations of the 
eighteenth century - an evidential one, which focused on establishing the veracity and meanings of sources, the other a narrative one, of which Gibbon's The History of the Decline and Fall of the Roman Empire is a good example, which nevertheless sought to present a true story. Yet at the same time, a great deal was lost. A good example of what was gained and lost is provided by the multivolume A Universal History from the Earliest Account of Time, launched in England in 1736 by an Islamic scholar, George Sale, and his amateur associates as a very successful commercial enterprise was quickly translated into the major European languages. This was indeed a universal history. There were volumes not only on the history of the European nations, but also on the Americas, East and South Asia, and Sub-Saharan Africa where the non-European peoples, including the Africans, were treated not as inferior, but as humans of equal dignity. It dealt not only with political events, but also with daily lives. The book was sharply criticised by the German Enlightenment historian, August Ludwig von Schlözer, who himself wrote a world history, for its poor scholarship, where imagination filled in for solid evidence - which was a justified critique - followed by the charge that it was not really history but constituted a mere accumulation of facts.

The turn from world history to a focus on Europe and Europe's domination of the world preceded professionalisation and was well developed in the eighteenth century. However, it had become an integral part of professional historiography well into the twentieth century. The idea of European superiority, often coupled with racism, was broadly accepted. At the turn from the seventeenth to the eighteenth centuries, the German philosopher Gottfried Wilhelm Leibniz still spoke of two great civilisations at the two ends of the Eurasian continent, the Chinese and the European, and also regarded Arab civilisation highly. But the impact of colonialism and imperialism changed this. Thus David Hume in the late eighteenth century considered "Negroes to be naturally inferior to the Whites". He continued: "There scarcely ever was a civilized nation of that complexion ... No ingenious manufactures amongst them, no arts, no sciences." This view persisted well into the twentieth century. As late as 1968, Hugh Trevor-Roper, Regius Professor of Modern History at Oxford University, dismissed Africa "as the unrewarding gyrations of barbarous tribes in picturesque but irrelevant quarters of the globe". He further wrote: "There is only the history of the Europeans in Africa. The rest is darkness and darkness is not a subject of history." ${ }^{\text {5 }}$

Professionalism also led to the exclusion well into the late twentieth century of women, Jews and ethnic minorities, not only from positions in academic institutions but also as subjects of historical study. This was directly tied to the way faculty was recruited. Women had no place at the universities until well into the twentieth century. Catherine Macaulay's History of England, the work of a liberal, early feminist, who challenged Hume's conservative interpretation of English history, had been well received in eighteenth-century England; she was totally ignored in the nineteenth century. Only in the second half of the twentieth century did women begin to play a very important role in North American, western European and Indian historiography. In the US, historians of the New History and Progressive History schools totally ignored the Black population. While the work of a Columbia University historian, James Randall, whose Civil War and Reconstruction (1937), explained the failure of the Reconstruction largely in terms of the racial inferiority of the Black electorate, was hailed as a standard work in the 1930s, W. E. B. Du Bois' Black Reconstruction (1935), which throws a very different light on this same electorate, now considered a classic, was not even reviewed in the American Historical Review. 


\section{Stage 3: The culturalist turn. Paris 1968 to Athens 2015}

It was only in the 1960s that the full impact of the changes wrought by the Second World War were felt with decolonisation, the decline of Europe on the international scene, the Algerian and Vietnam Wars, the civil rights movement in the US, the emergence of feminism, and student uprisings throughout the world, in Paris, West Berlin, Mexico City, South Korea, Tokyo, and on campuses in the US. These protests centred around the social, racial and sexual inequalities in the existing societies, but they went beyond a critique of the capitalist economic order, to a much broader challenge of the culture on which it rested. This discontent was not limited to capitalist countries but also found expression in protest movements in communist-dominated Poland and in the Prague Spring, and somewhat later in South Korea and the People's Republic of China, which ended tragically in the massacre of students in Gwangju and in Tiananmen Square. All this would have an impact on the reshaping of historical thought and writing, as would the fundamental changes which took place in the composition of the student body and in the recruitment of faculty. The number of students increased dramatically, to include students who had been underrepresented such as women, or largely excluded as members of ethnic and racial minorities. And at the same time these same groups for the first time became important subjects of history. And new areas of study were opened, the history of women not only in a political context, but aspects of women's lives, emotions, sexuality and the relation of genders. The various ethnic and racial groups began to explore and reconstruct their past, aware of the discriminations it had involved. A shift took place from the traditional reliance on documentary evidence to oral sources and to the exploration of individual and collective memory.

It is at this point that the turn took place from social science to cultural approaches to history. I want to make a distinction here between the cultural and the linguistic turn as approaches to the study of history, on the one hand, and as theoretical doctrines, on the other. As a cultural approach, it threw light on aspects of history which had been neglected by much of social science-oriented history, although at times it overlooked the political and social context of culture. As a doctrine, it denied the possibility of rational inquiry into the past.

The work of Lynn Hunt exemplifies well the transition from the old to the new historiography and beyond it. Her Politics, Culture, and Class in the French Revolution (1984) offers a good example what the cultural turn means at its best. While when she set out in 1976 to write the book, she had intended a "social history of revolutionary politics"; she now realised that the political side was only a part of the story, but as the title of her book indicated she by no means neglected the political side or the role of class, but saw them in a broader cultural context, in which symbolic gestures, images and rhetoric all played their part. In this way, the cultural turn constituted a clear enrichment. The linguistic turn heightened the awareness of how language influenced political activity. But a gulf arose between practicing historians and literary theorists. While serious historians recognised the cultural context of political and social history, some literary academicians and some philosophers turned to radical forms of epistemological relativism. They would agree with Jacques Derrida when he argued that "il n'y a pas de hors-texte" (there is no external reality to which language refers), ${ }^{6}$ that there are only texts. Michel Foucault held that the text exists independently of its authors, whose intentions do not enter. From the position of cultural anthropology, Clifford Geertz maintained that cultures represented texts, "webs of significance", which must be confronted directly 
as "others", ruling out theory-guided questions.? From the perspective of literary theory, Hayden White maintained that "there has been a reluctance to consider historical narratives as what they most manifestly are: verbal fictions". ${ }^{8}$ Then, of course, there were historians such as Joan Scott, who preached the gospel according to Derrida, but conducted archival research in pursuit of serious questions of feminist concern in a very traditional manner.

Marxism presents another good example of the transition from the old to the new culture-oriented historiography. But it was not the Marxism of Marx or that of Lenin, but a revision of orthodox Marxism generally called western Marxism. Two quite different Marxist writings, Antonio Gramsci's Prison Notebooks, written in Mussolini's prisons, and György Lukács' History and Class Consciousness (1923), moved away from Marx's materialist interpretation of history and stressed the role of culture. While Lukács still clung to Marx's idea of a revolutionary industrial proletariat, Gramsci expanded Marx's concept of class to include the masses of nonindustrial workers, men and women, in industrially less-developed countries, whom he denoted as the "subaltern classes", subordinated to the established order not just by political and economic power, but by "cultural hegemony", the control which the dominant culture exerted over their minds. It was only in the very different atmosphere of the 1960s that their work became well known. It was the Gramscian revision of Marx which was to play an important role in the historiography of countries of the so-called third world, with the launching of Subaltern Studies in India in 1982, which in turn affected historical writings in Latin America and Sub-Saharan Africa. E. P. Thompson's widely accepted redefinition of the English working class in cultural terms went in this direction. But Thompson was soon criticised for clinging too closely to Marx's elitist concept of an essentially male industrial working class. The History Workshop in England sought a broad history from below of the lives of working people, men and women, in capitalist economies. Charles van Onselen, part of the History Workshop in South Africa, wrote a history of the rural poor, white and black, in Witwatersrand under the impact of industrialisation and urbanisation including the very classes - the unemployed, the criminals, the prostitutes, in other words the very Lumpenproletariat - which interested neither Marx nor Thompson.

The importance of Marxism for the new history should not be overstated, but it reflected changes which now took place in much of historiography generally, Marxist as well as non-Marxist. There was a reaction now against social science models, including Marxist ones, as they had been practiced in the past; histories of anonymous social structures and processes of change, in which the life experiences of concrete human beings had no place. A good example of a history without people is Emmanuel Le Roy Ladurie's The Peasants of Languedoc (1966), in which he dealt with the history of the peasantry, relying largely on statistics, in a large region in southern France in terms of demographic and price cycles, in which individual human beings, except for a brief interlude about the carnival in Romans, had no part. Nine years later in 1975 in Montaillou, he went in a completely different direction, this time dealing with the lives of the individual members of a community of religious heretics in a small village in early thirteenth- century southern France, with the interrelation between its inhabitants, their emotions and sexuality. their religious beliefs; using no statistical sources but instead the protocols of spoken testimony.

An increasing number of historians throughout Europe and North America now turned to what the Italians called microstoria, centring on the lives and fates of individuals in a historical setting. In the 
place of the master narratives which had been central to much history before, there was now a return to a multitude of narratives. This also involved a repudiation of ideas of modernisation which at their core proceeded from a Eurocentric perspective. The outcome of history could no longer be the fulfilment of western norms. There are two responses to the question of modernisation: one originating very early with the radical right, with thinkers like Friedrich Nietzsche, and with Martin Heidegger, who ended up with the Nazis, but taken over by thinkers on the left, including Michel Foucault and including some members of the Frankfurt School, including Herbert Marcuse, who now held the rational outlook of the Enlightenment responsible for the catastrophes of the twentieth century, a view shared by the Indian philosopher Ashis Nandy, who considered the secular worldview of the Enlightenment and its scientific rationality responsible for the wars, gulags and genocides of the twentieth century. It is striking that this view is not shared by many thinkers in developing countries such as India and China. Thus in China, despite the official Marxist ideology of the communist government, for many historians the modern west represented a goal to be approximated. And the Indian historian Dipesh Chakrabarty in Provincializing Europe (2000) stressed, on the one hand, that modernisation takes on different forms in different cultural settings, and, on the other hand, that there are basic elements of Enlightenment thought, including the commitment to human rights, without which a modern Indian nation cannot do.

\section{Reflections on the present state of historical studies}

Now to 2015. There is a tendency among some historians, like Lynn Hunt in her most recent Writing History in a Global Era (2014), to conclude that the cultural and linguistic turns belong to the past in an increasingly global era. I agree, but would not go quite so far. To get an admittedly superficial impression, I shall look at the programme of two recent annual meetings, that of the American Historical Association in January 2015 and that of its German counterpart in September 2014. In the American programme we find many sections along the lines of the cultural turn, including an almost obsession with topics of sexuality and homosexuality. These topics play a much more limited role in the German programme. There is a break away in both programmes from nation-oriented topics: in the American programme there is a strong global and in the German programme a European perspective. Several sessions in the American programme are devoted to race, sex and slavery. Few sections in the German programme deal with German topics; the focus is now much more than in the American programme on the twentieth century with its horrors. It would be interesting to compare the present programmes with programmes 40 or 80 years ago and make a transcultural comparison which would also include non-western countries.

\section{Final remarks}

We live in an increasingly global world. Only very belatedly have historical studies taken this into account. Eurocentrism has been widely rejected, but in fact it is still very much alive. As Dominic Sachsenmeier has pointed out, in a recent ten-year period 13 times as many books have been 
translated from western languages into Chinese than the reverse. There is a considerable Chinese body of literature on global topics which, except for a limited number of Sinologists, has simply been ignored. China is still not a part of the international discourse. In the case of largely Anglophone India this may be different. It was encouraging that that the International Congress of the Historical Sciences took place in China in 2015.

A final word about professionalism. The reorientation of historical studies and writing in the last decades of the twentieth century challenged the basic assumptions of the prevailing historiographies, but generally accepted the professional character of historical studies without any major criticism. The gulf between professional scholarship and the public is much greater today than it was in the nineteenth century. And within the academic institutions, including those devoted to teaching undergraduates, the command is "publish or perish", even if many of the publications resulting have little relevance for teaching. This ritual needs to be reformed, but it will be very difficult to break through the entrenched policies of recruitment and promotion. Similarly, despite the talk about interdisciplinary approaches to history, only limited progress has been made. But the departmental organisation of universities and colleges generally throughout the world works against truly interdisciplinary history. Perhaps the example of the Maison des sciences humaines replacing traditional departments offers an alternative.

There is no dominant model of historical studies today, and that is good. An overview of the two programmes I mentioned shows, a large diversity in historical approaches, but the culturalist model is still very much alive in the US. The limits of the three models I discussed are very clear now. None of them were truly comprehensive. The Rankean model, with its radically elitist view of history, turned out to be out of step in an emerging democratic world, and the social science model had little concern for the human factor and showed little interest in the cultural aspects of society. The culturalist model brought the cultural side back into history. It rightly pointed at the limitations of the older historiographies, particularly the social science models. Yet in its more radical forms, it not only neglected the economic and social context of culture, but its extreme relativism denied the very possibilities of rational inquiry needed to understand the global world in which we live. We badly need a social science to understand this world, but one which does not return to the older model, but considers the manifold aspects which make up our rapidly changing world. To end on a positive note, a lot has been gained in the last decades, with the opening of new topics and the exploration of new methodological approaches of which the older historiographies did not dream. Despite the shortcomings which I have pointed out, today history is much richer than it was ever before.

\section{NOTES}

1 Emmanuel Le Roy Ladurie, The territory of the historian, trans. Ben and Sian Reynolds (Chicago: Hassocks, 1979), 15.

2 Geoffrey Barraclough, Main trends in history (New York: Holmes \& Meier, 1979), 89.

3 Robert Fogel and Stanley Engerman, Time on the cross: the economics of American negro slavery (Boston: Little, Brown, 1974). 
4 David Hume, "Of national characters," in The Philosophical Works of David Hume, vol. 3 (Edinburgh: 1826), 236.

5 Cited in Toyin Falola, "Nationalism and African history," in Turning points in history: a cross cultural perspective, ed. Q. Edward Wang and Georg G. Iggers (Rochester: University of Rochester Press, 2002), 211-12.

6 Jacques Derrida, De la grammatologie (Paris: Minuit, 1967), 227. My translation.

7 Clifford Geertz, The interpretation of cultures (New York: Basic Books, 1973), 5.

8 Hayden White, "The historical text as literary artefact," in Tropics of discourse: essays in cultural criticism (Baltimore: Johns Hopkins University Press, 1978), 82 